\title{
A Corpus-Based Evolution of Chinese Englishes from a Language Contact Perspective
}

\author{
Yihua Zhang ${ }^{1} \&$ Hanfu $\mathrm{Mi}^{2}$ \\ ${ }^{1}$ Guangdong University of Foreign Studies, Guangzhou, China \\ ${ }^{2}$ University of Illinois at Springfield, Springfield, IL, USA \\ Correspondence: Hanfu Mi, University of Illinois at Springfield, 1 University Plaza, Springfield, IL, 62703-5407, \\ USA. E-mail: hmi2@uis.edu
}

Received: August 16, 2019 Accepted: September 15, 2019 Online Published: October 13, 2019

doi:10.5539/ijel.v9n6p37

URL: https://doi.org/10.5539/ijel.v9n6p37

\begin{abstract}
Many linguistic studies have examined the notion of Chinese Englishes. However, the terms used remain vague, and the concepts behind them are often confusing. The present paper attempts to investigate the inner characteristics and formation mechanisms of Chinese Englishes, and to identify their differences from a perspective of contact linguistics. The subsequent discussion is directed to the phonological, lexical, morphological, and syntactic characteristics (or motivation) of Chinglish-Chinese English and China English based on relevant corpus data and documents, focusing on the profiling description of China English, including phonological and grammatical transference, and semantic extension through calque.
\end{abstract}

Keywords: Chinese Englishes, China English, China specific words, language contact, corpus-base study

\section{Introduction}

Economic globalization imposes language contact on different linguistic communities. In today's international economic and trade exchanges, English has become the de facto international language. It is, in a sense, no longer the exclusive language for some countries, simply a tool of international political, economic, and technical exchange and cultural diffusion. That is why the concept of world Englishes has emerged and of which Chinese Englishes are an essential part.

The history of Chinese Englishes is quite long, and may be traced all the way back to 1637 when the first business deal was made between English traders and the merchants of Guangzhou (Canton or Kwangchow). Such language contact resulted in a unique lingua franca called Canton English (Williams, 1836, p. 432), which emerged in communication solely due to the needs of business activities. This began to decline towards the end of the nineteenth century as normative English was gradually taught in schools and colleges. English in China thereby has undergone a rather tortuous evolution, roughly from Pidgin English to China English through Chinglish and Chinese English.

In recent decades, a great many scholars have been actively engaged in studying the variety of Englishes (Cheng, 1992; Singh, 1995; Deterding \& Sharbawi, 2013; Jette \& Edwards, 2016), and international Englishes (Smith, 1983; Kachru, 1990, 1992; Crystal, 1997; Kirkpatrick \& Xu, 2002; Matsuda, 2003; Davis, 2010; Matsuda \& Friedrich, 2011). A number of terms have been used, such as World Englishes, global Englishes, Asian Englishes, and a lingua franca, with the Three Concentric Circles of English proposed by Kachru (1992) emerging as the most influential theoretical model. The Inner Circle covers the English mother tongues; the Outer Circle covers the non-native varieties of English used as a second language, and the Extending Circle covers the English used as a foreign language. Chinese Englishes, belonging to the third circle, have increasingly become an important topic in linguistics, with numerous studies examining the differences among various forms of Chinese Englishes (Jiang, 1995; Kerr, 2001; Bolton, 2003, 2012; Eaves, 2011), the features of China English and Chinese English, and the nativized forms of English in China (Todd \& Hancock, 1986; Wang, 1991; Kachru, 1992; Li, 1993; Zhang, 1997; Jin, 2001; Jiang \& Du, 2001, 2003; He \& Zhang, 2010; Eaves, 2011; Zhou, 2013; Jiang, 2014).

Up to now, the stages of development of the Chinese Englishes, the terms used and their respective meanings remain vague, and their concepts are often confusing; the lexical and language instances used in research are not 
consistent and systematic, mostly in the form of a case study from the perspective of language, translation and teaching, which may not adequately define and reveal the motivation and characteristics of the variety of Chinese Englishes. This paper draws support from related corpora (see Section 2), which enable the researchers to systematically elaborate the emergence, development, and features of each variety of Chinese Englishes from the language contact perspective.

\section{Language Contact Study on English Varieties}

Language contact occurs whenever two or more speakers who do not share the same language need to communicate (cf. Thomason, 2001, p. 1). The eagerness to achieve effective communication can lead to a compromise between the languages involved, thereby giving rise to a rich variety of outcomes (e.g., borrowings, pidgins, and language variants).

These outcomes are inextricably linked to the factors such as the length and intensity of contact. Due to long-term and intense language contact between English and Chinese, English has exerted great influence upon the Chinese language; on the other hand, English has borrowed a significant number of vocabulary items from Chinese in the course of its evolution. Language contact thus induces linguisitc change and transference not only in actual communication, but also in second language learning and reading texts such as words of literature, cultural writings, and dictionaries. Still many other contact situations have caused various language transfers and changes, often so extensive that a new variety of languages has been created, e.g., Singapore English, Malaya English, and in recent years, China English. Therefore, language contact has proven to be an effective approach to studying English varieties. Weinreich (1953/1979) put forward a systematic theory to account for the causes and outcomes of language contact from a social and psychological perspective. A great many scholars (Moravcsik, 1978; Danchev, 1988; Silva-Corvalán, 1994; Thomason, 2001; Treffers-Daller, 1999; Winford, 2003, 2005; Escure \& Schwegler, 2004; Muysken, 2013) since then have been engaged in language contact related studies. These efforts have contributed to the increasing interest in language contact between English and other languages, focusing on different aspects, such as contact-induced change from one language to the other, the influence of English and Chinese upon each other through borrowing, norms and variety of Englishes, perceptions of China English, and translation of China-specific words (Cannon, 1988; Meeuwis, 1991; Wu, 1998; Kirkpatrick \& Xu, 2002; Zhang \& Shi, 2008; He \& Zhang, 2010; Kui, 2011; Cui, 2012; Shi, 2014; He, 2015).

Winford (2003, pp. 23-24) provides the main linguistic outcomes and relevant examples of language contact based on different types or degrees of contact. The former consists of language maintenance, language shift, and language creation. In terms of his classification, language maintenance, in some ways, refers to borrowing, language shift to language transference, and language creation results in pidgins and other varieties of English. In this respect, no matter what kinds of Englishes are encompassed, they are contact-induced variants of the English language. In other words, they are outcomes of British English that came in contact with other languages at a specific time, and in specific social and cultural environments. Consequently, the variety of Englishes is marked with the cultural, historical, and social brand of relevant countries.

Therefore, in terms of understanding the formation mechanism and development trend of different English variants, it is more meaningful to define various Englishes from the perspective of language contact. For example, the reason for classifying Australian, British, and New Zealand English into the same circle is that English dominance exists in those language societies. By contrast, the Englishes in India and Singapore, and in other countries such as mainland China where English is used as a second and foreign language, may be influenced by the speakers' mother tongue or L1, and the degree of contact-induced change is therefore more considerable.

The analysis of the influence of language contact upon the relevant languages requires a large amount of language data or records extracted from real language communication. The language materials involved in this research include the following (Note 1):

1) Chinese Learner English Corpus, established by Guangdong University of Foreign Studies (GDUFS), China. This is a record of English essays written by Chinese EFL learners ranging from high school to college students, providing first-hand material for extraction of the interlingual or Chinese English.

2) China-Related English Corpus, also founded by GDUFS. The Corpus includes exclusively English material describing objects and events which occur in China, and more or less specific to the Chinese culture.

3) Oxford English Dictionary Online (OED), and

4) Chinese loan words included in other British and American English Dictionaries, as well as China English wordlists by Cannon (1988) and others. 


\section{Discussion}

\subsection{Mechanism and Characteristics of the Formation of Chinese Englishes}

Language contact between English and Chinese began when trade between the United Kingdom and China started in 1637, although both parties did not understand each other at first. In 1715, the British East India Company defeated the other competitors, gaining monopolistic power of trade with China. It was in the period of 1685-1715 that Chinese and English language contact brought about language creation (Wu, 2001). The outcome of this contact was the famous Canton English. From 1715 onwards, Chinese businessmen learned a strange dialect, that is, Canton English, which became the lingua franca for foreign trade in China. Since then, the British trade in Guangzhou increased year by year. In 1853, Shanghai became the center of foreign trade and the center of business for Britain moved from Guangzhou to Shanghai; Canton English immediately spread in Shanghai. It had, however, departed from its birth land, and the subject of language contact was switched from English-Cantonese into English-Zhejiang and Shanghai dialect. The English was then naturally marked with local Shanghai features, and a new hybrid of English-Chinese came into being: Pidgin English, which has been popular in China since the 1870s, and the British geographer and linguist Burton noted that "in the near future" Pidgin would become the whole world, lingua franca (Zhou, 2013). However, with the rapid development of foreign trade, language contact became increasingly close, and the influx of foreigners was no longer limited to missionaries, merchants, and diplomats. Since language contact involved people of all walks of life, spontaneous Pidgin English was not able to meet the need for in-depth exchanges.

In such a situation, the interest in the normative English education increased, the popularity of Pidgin English began to wane. In China especially in recent decades, more and more people have become engaged in English learning. However, only a few learners of English are able to master the language well, while most learners of English become stagnant as interlanguage users due to fossilization. Therefore, at this stage of English learning, apart from China English, there also exist Chinglish and Chinese English.

As stated above, since the emergence of Canton English, English in China has experienced distinct stages of evolution; thus, the term Chinese Englishes is used in this paper to represent different varieties or status of English within different language contact periods in China. The following discussion is devoted to the structural and functional characteristics of Chinese Englishes.

\subsection{Chinglish and Chinese English}

Chinglish and Chinese English are discussed comparatively here, because the two terms are often confused. Some scholars (Xie, 1995; Zhang, 1997; Kerr, 2001) believe that there is no clear distinction between the two terms, and describe them as being "at the opposite ends of a continuum"; they are rather an interlanguage, usually manifested as Chinese-style syntax with English words. Others (Kachru, 1988, 1992) consider Chinese English as a variety of English, much like the terms American English or Japanese English. Still others (Eaves, 2011) tend to define Chinese English as an interlanguage, and Chinglish as a nonsensical form of language, usually produced by deficient translation devices or speakers/writers with a low proficiency level.

We agree with Eaves's (2011) definition of and distinction between Chinglish and Chinese English, because in our textual research, the former is usually considered as bad English, and the latter as English with Chinese style. Chinglish is thus of less value than Canton English or Pidgin English, for the latter served functional purposes historically, contributing greatly to international trade in the $18^{\text {th }}-19^{\text {th }}$ century, while the former can hardly be operational in actual communication and should be therefore rejected. Eaves (2011) offered some examples to support her argument, e.g., the term 智力玩具 (zhìlì wánjù) is translated as mental toy, and 回程道 (huíchéng dào) as backbarkt, while a more appropriate translation would be intellectual toy and return route or way back. A great number of such examples are readily available; several are provided here to further illustrate this point (Note 2): 
Table 1. Examples as appeared on public signs

\begin{tabular}{|c|c|c|}
\hline Chinese Expression & Chinglish Translation & Acceptable English \\
\hline \multirow{5}{*}{ 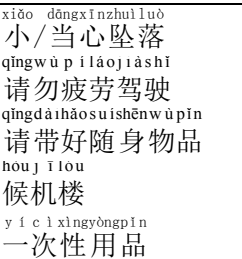 } & Take care to fall; Caution, drop own & Danger! Risk of falling! \\
\hline & Do not drive tiredly & Don't drive when tired. \\
\hline & Please take good personnel luggage & Please take your personal belongings with you! \\
\hline & Hou Machine Building & Terminal Building \\
\hline & A time sex thing & Disposable goods \\
\hline
\end{tabular}

The above examples show that Chinglish is a hybrid of Chinese and English, and often has a facetious reading, they cannot express the meaning of the Chinese phrases, some are even not meaningful at all (especially, hou machine building, and a time sex thing), and some others may have the opposite meaning, e.g., take care to fall means make the effort to fall. Therefore, Chinglish is not, in fact, an interlanguage; it is a largely meaningless, problematic form of English that usually results from word-for-word translation, even from poor machine translation, or just a misunderstanding of English.

Chinese English, as the interlanguage spoken by Chinese learners of English (EFL) has its own developing rules and characteristics. Interlanguage may be used to refer to particular regional and/or national varieties of a widely spoken language (Lipski, 1994; Escure \& Schwegler, 2004). However, as a technical term, it has been used more frequently in SLA to specify a learner's language with goal-directed development towards the target language system, which shows systematic features both of the target language and of the learner's mother tongue (Selinker, 1972; Corder, 1981, p. 67). Within the framework of interlanguage, errors are not viewed as incorrect utterances with the target language as the norm but rather each utterance reveals the pattern of a learner's developing interlanguage (Ellis, 1987).

In fact, when two languages come in contact, linguistic interference, code switching, language imposition or transfer may intervene in the process. Selinker (1972) identified five main factors which cause errors in second language acquisition, among them are language transfer and overgeneralization of the L2 rules. In addition, strategies of L2 communication exercise considerable influence upon Chinese English. In contact linguistics, this is related to language imposition or transfer and interference.

1) Language Imposition or Transfer

Linguistic imposition takes place via the agency of speakers for whom the source language is dominant (Winford 2003, p. 10), as when a Chinese native speaks English. In imposition, they transfer varying degrees of their L1 structure to an external recipient language. However, there exists considerable divergence in conceptual, metaphoric and prosodic systems as well as cultural symbolization between Chinese and English, which results in an interlanguage with China-specific features.

(1) We talk heart each other. (ST6) (Note 3)

(2) Some knowledge can't be learned from universities. (ST6)

(3) According to my opinion, this idea is not proper. (ST6)

(4) ... to taste the fresh feeling. (ST6)

(5) ... to teach the young people the theoretical knowledge. (ST6)

(6) We should also open some classes... in order that...study more knowledge...(ST4)

The imposition here leads to the shift of some specific features in the target language, and to the creation of new expressions in the model of source language due to cross-linguistic influence. The above Chinese English examples exhibit typical interlingual features, where evident traces of Chinese thinking can be found: talk heart

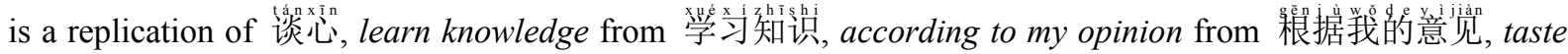

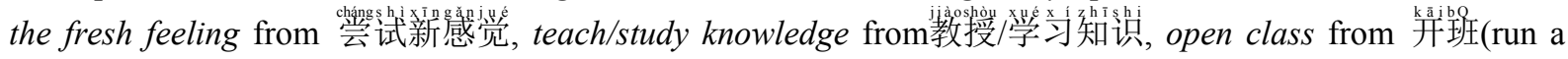
training class). The above structures may be grammatically correct, but are not acceptable on the lexical and collocational levels.

According to corpus statistics, such errors are quite common. For example, in about one million words in the Chinese Learner English Corpus (CLEC), 2,923 collocation errors have been found, the distribution value (D 
value) is up to 0.9 ; and those of verb-noun collocation amount to 1,566 , accounting for $53.58 \%$ of the total collocation errors. Research shows that $51 \%$ of the interlingual errors committed by Chinese EFL learners have occurred due to mother tongue interference (Shu, 1996), while EFL learners from European countries are rarely affected by their mother tongue transfer in the above examples (Note 4). Therefore, Chinese learners' errors have their unique characteristics, and it is important to be aware of this in the process of L2 teaching.

2) Interference of the Overgeneralization of L2 Rules

Because Chinese is a non-inflectional language, and has no morphological change, the structure and meaning of a sentence is determined by word order. When Chinese EFL learners come in contact with English, their lack of familiarity with English inflectional and grammatical rules may result in their organizing the English sentence in a Chinese way, or mistaking a restricted rule for a general rule. The latter leads to overgeneralization of the target language rules, and thus forms specific features of Chinese English.

According to retrieval statistics of the CLEC, 2180 errors are sorted out in word building, and a considerable number of them are due to the overgeneralization of syntactic and morphological rules. The following are some extracts from the corpus:

(1) Overgeneralization of adding the suffix “-ing”: their useing, world's champion of runing, at the very begining, the good shoping, It's good eatting. The authors do not know the restriction for adding "-ing": suffix "e" is to be omitted and the single consonant letter at the end of the stressed closed syllables should be doubled; and finally, the double-letter rule is applied to "eat", but this unintentionally violates the rule that the consonant after a double vowel syllable cannot be doubled.

(2) Overgeneralization of adding the suffix "-ed": I have builded, It maked me, I thinked, the bike striked, the bright moon has rised, The branches spreaded. The students have learned the rules to form past tense by adding "-ed", but they are not aware of that there are irregular verbs, to which "-ed" cannot be added.

(3) Overgeneralization of adding a functional suffix: The adjudgers are poor in, the enemy's attacktion, their greedyness, the weather is rainly, be regarded as understoodable, if we occupationize. The authors know the rules for changing another part of speech into nouns, adjectives, and verbs by adding "-er, -tion, -ness", "-ly, -able" and "-ize" respectively, but have no idea which words should follow the suffix addition rule and which words should not.

(4) Overgeneralization of adding plural markers: mans' life, all the heros, boxes of strawberrys, people's lifes, detailed analysises, the Eskimoes. The authors know the rule of creating plural form by adding "-s"; however, they have not yet mastered the specification of irregular plural noun changes. In addition, they do not know the requirement for change at the end of some words before adding "s". As for Eskimoes, the error occurs due to the overgeneralization of adding "-es" to a term ending in "o".

Overgeneralization can occur at all the levels of linguistic structure in Chinese EFL learners' English. This phenomenon is hardly observed in the International Corpus of Learner English, since the search results show that there are no such errors other than three instances of "heros". This kind of overgeneralization of the target language rules may also be China-specific.

3) Interference of the Strategies of L2 Communication

EFL learners tend to use strategies of L2 communication, such as approximation, generalization, and paraphrase in order to make up for the gap between what they want to say and what they are able to say in the foreign language. The most common strategy for Chinese EFL learners is to use an abstract word (usually of high frequency) and superordinate words to replace subordinate words with specific meaning. As Gillard and Gadsby (1998) assert, after their contrastive analysis of the frequency words big, enormous, huge, massive involved in London Lund Corpus (LLC) and British National Corpus (BNC), the proportion of hypernyms instead of hyponyms is much higher in foreign language learners than in the natives. In Chinese English, this situation may be even worse. For example:

the bikes disappear. The bad sense got in our hearts.

instant, fake food with bad quality will make you

cause other dangers for its bad function

the books won't do bad. No, there is so much wrong

We have adequate knowledge so we can help the bad middle school students

But some bad men make fake commodities 
In the above examples, the word "bad" may imply the following meanings: unpleasant, awful, terrible, poor, low, inferior, harmful, slow or fraudulent. Among them, some are hyponyms of bad; others have meanings close to but more specific than bad. When they are replaced by bad, the sentence meaning seems bland, or simply wrong. The statistical data of the corpus show that high frequency words such as do, have, get, give, make, take are widely overused. The frequency of make in its various forms in CLEC is 4,826, i.e., $207.8 \%$ of that in the Brown Corpus. Among them, 2,621 sentences contain the unique form make, and the interlingual errors amount to 653, accounting for $24.91 \%$ of the total number of sentences. Seventy errors involve verb-noun collocation and consist in the overuse of high frequency words, e.g., make (take -s) measure (Note 5), make (acquire) our knowledge, make (achieve) success, make (establish) good relationship, make (implement) the reform, make (place) focus on, make (live) a better life, make (take) responsibility for, make (do, try) my best, make (do) great harm to, make (draw) a conclusion, make (take) further steps, make (have) a nice chat. We used these collocations as an index to search for similar errors in the International Corpus of Learner English, but only one item was found. Obviously, this kind of interlingual feature is even more China-specific.

Interlanguage is subject to various forms of interference, just as Weinreich $(1979$, p. 1) argued they are rather instances of deviation from the norms of either language as a result of language contact. It should be noted that Chinese English differs from Pidgin English in that the former is, in some way, rule-governed and ordered, rather than being an error-ridden version of the target language.

\subsection{A Profile of China English and China-Specific Words}

There have been numerous definitions of China English since the term was proposed. It was used to refer to English expressions translated from China-specific words, such as Four Book, imperial competitive examination, eight-legged essay, or xiucai.

Wang (1991) holds that the concept of China English should include: being used by Chinese people in China, with Standard English as its core and unique features. Li (1993, p. 19) is of the opinion that the use of China English should not be restricted to Chinese native lands; the term Standard English seems arguable, and should be replaced by Normative English, which may conform to the general rules of the English language. Thus, he defined China English as based on normative English without the interference of a speaker's mother tongue, and adapted to express things specific to Chinese culture by means of transliteration, borrowing and semantic revival. Some scholars (Xie, 1995; Jiang, 2001; Liu, 2008) challenged Li's definition from the perspective of cross-cultural communication, asserting that Chinese interference actually exists in China English, which is an English variety used by Chinese people in cross-cultural communication. Jiang (1995) supports Xie's views, arguing that China English is a "nativization" of normative English, and nativized English is different from native English in phonology, lexis, syntax and discourse. Many others (Jia \& Xiang, 1990; Jiang \& Du, 2001, 2003; Jin, 2001; Jiang, 2001; Poon, 2006; Eaves, 2011) are engaged in the study of China English from different perspectives; although there has been no unanimous definition of China English to date, we have attempted to generalize about the concept of China English from the relevant studies. Accordingly, it is:

$>\quad$ an English variety based on normative English (the inner circle of English);

$>$ a hybrid of British and American English in both spoken and written forms;

$>$ a varied, near-native pronunciation, with more or less Chinese accent;

$>\quad$ a vocabulary and expressions specific to China and used in and outside China for cross-cultural communication (an international variety);

$>$ idiosyncratic lexis, syntax and distinct discourse varieties due to the effect of language contact (native Chinese transfer or shift, instead of interference).

From the above discussion, China English is here defined as a norm-based English variety used by Chinese people for international communication, with a lexis, pronunciation, syntax and discourse characterized by Chinese culture due to both the nativization of normative English and transference of Chinese through borrowing, calque, and creation. In addition, Chinese loanwords, which have been included in English dictionaries and used in British and American media, naturally form an important part of China English. This definition is based on contact linguistics, and conforms to the embodiment philosophy and usage-based rules of cognitive linguistics. The following discussion is focused on the characteristics of China English with transference from Chinese focusing on grammaticalized lexis from the perspective of language contact. As Kachru (1992) noted, a non-native English speaker's native linguistic and cultural life may be transferred into English. Thus, the specific features of Chinese may transfer into China-specific English (China English) in different ways.

1) Phonological Transference through Borrowing or Transliteration 
Phonological transference takes on different forms in different periods of the development of Chinese Englishes. In the early stage of Chinese English (Canton English), the Chinese borrowing are mainly based on transliteration, which was greatly influenced by "A Latin Alphabet Spelling Scheme for Chinese Characters", which Michele Ruggieri and Matteo Ricci developed for their Portuguese-Chinese dictionary (1583-1588) - the first ever European-Chinese language dictionary, as well as by various translation works, grammar books, and dictionaries by Morrison (1823). For example:

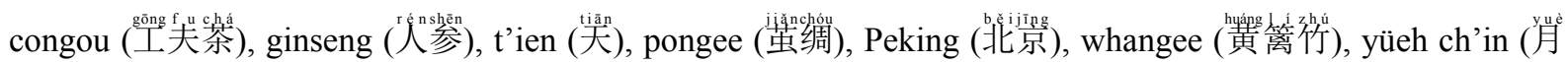

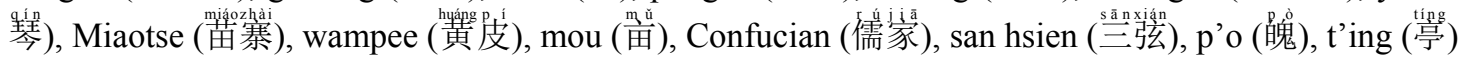

Since the alphabet system recorded in the Portuguese-Chinese Dictionary is just a rough spelling scheme, without phonetic transcription details, it was subject to various modifications and improvements (Trigault, 1626; Morrison, 1823; Williams, 1856, 1874). Besides, all these phonetic schemes are based on the Chinese Southern dialect, especially Cantonese. Probably for this reason, Wade compiled the Yu yen tzu erh chi-a textbook dedicated to the description of colloquial Chinese based on Peking Mandarin in 1867. That was the birth of the Wade-Giles Romanization System. The phonetic transcription inherited some characteristics of Morrison's phonetic system, and simplified the notation symbols, so that the notes can be closer to both English and Mandarin pronunciation. Here are some typical examples:

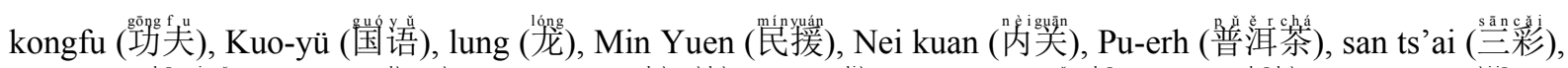

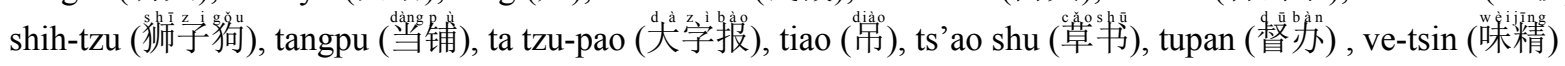

Since then, the Wade-Giles Romanization System has been widely used in the translation of China-specific words, and adopted in English dictionaries for phonetic transcription of Chinese loanwords until 1958 when the Scheme for Chinese Phonetic Alphabet (Pinyin) was issued. It is considered a better solution to transcribing Chinese words in the Latin alphabet, and closest to normative English pronunciation.

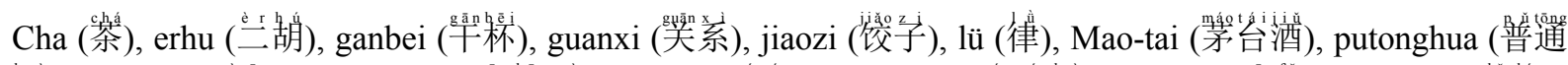

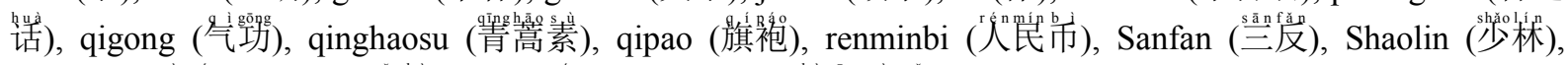

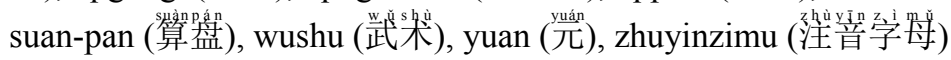

A number of Chinese loanwords, even included in OED, have experienced a spelling change in the light of Pinyin, for example, Peking $\rightarrow$ Beijing, Amoy $\rightarrow$ Xiaman, weich'i $\rightarrow$ weiqi, Taoism $\rightarrow$ Daoism, ta tzu-pao $\rightarrow$ dazibao, etc.

\section{2) Grammatical Transference through Calquing}

The term calque refers to the process of creating a word or syntactic construction through borrowing the meaning or morphological structure from another language. (cf. Trésor de la langue française informatisé) (Note 6). A China-specific word or expression, once it has come into English as a loanword, will undergo an assimilation process through calque from both sides of language contact.

In the first case, the English expression would be a calque of the Chinese equivalent, where a transference of Chinese grammatical features would occur, inducing a certain change in the target language construction. For

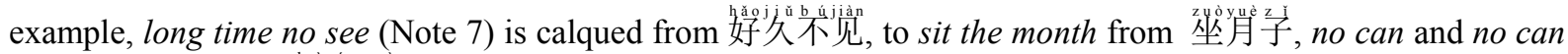

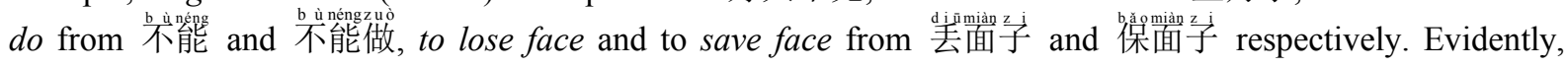
the above China English expressions are structured on the model of China-specific words, and characterized by Chinese syntactic construction.

In the second case, the extension of China English would be a calque of the vocabulary building mechanism of both English and Chinese, where a transference of English grammatical features would occur, which would induce a certain change of the source language (China-specific words) construction. For example, Chinese

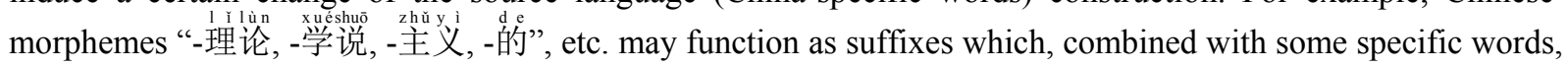
form new lexical items. English also has such a mechanism and morphemic equivalents, so that a number of new items may be formed based on the combination of China-specific words as root and English morphemes as

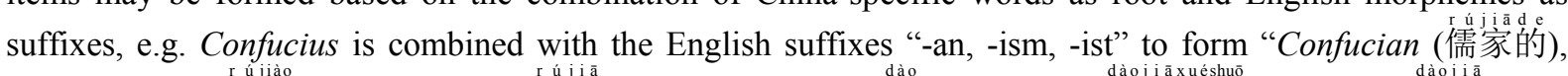

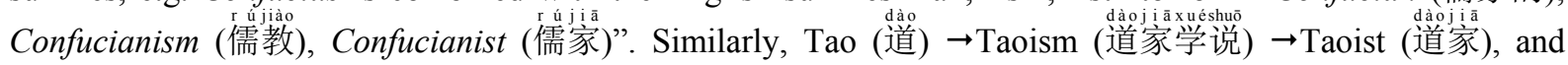




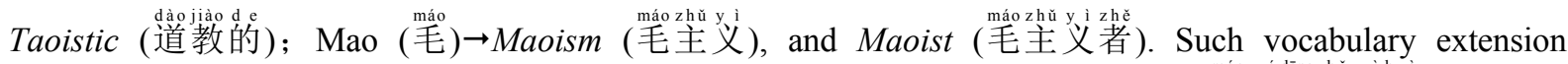

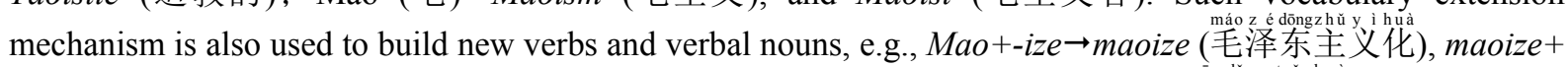

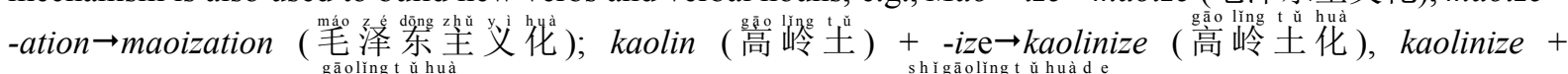
-ation $\rightarrow$ kaolinization (高岭苓土化), kaolinize + -ing $\rightarrow$ kaolinizing (使高嵪岭土化的).

Additionally, some China English words or morphemes such as China, Chinese, sino- silk, tea, kaolin are very productive; they can join a large number of other words to form compound words.

It should be noted that, in the beginning, when Chinese borrowings seeped into English, they were usually written in italics, or with a hyphen to separate syllables (characters) of single lexical units (e.g., kong-fu, yang-ko), in order to tell readers that these had not become normal words yet. With the increase in the frequency of use, China English words are no longer written in italics and the hyphens are being gradually omitted from the two syllable words (e.g. kongfu, yangko). As for plural forms, the measure words have no inflectional suffixes, e.g., three yuan, five li, etc.

\section{3) Semantic Extension of China English Words Through Calquing}

Semantic extension is a common phenomenon in lexical evolution. It refers to the process where a word acquires a new meaning through figurative extension based on its basic meaning. When a China-specific word is assimilated into English, it may extend its meaning through a calque from its Chinese origin.

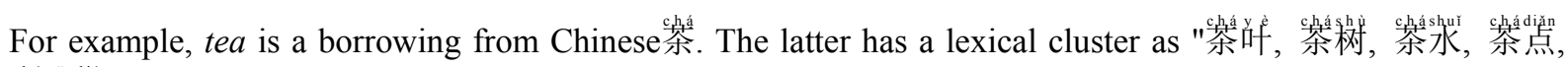
啉饮料." Given the consideration of cognitive economy, China English has incorporated all the above five Chinese lexical items or rather senses into a single word tea by means of semantic calque, that is, the five individual senses are transferred to tea, while their lexical forms are abandoned. So the word, tea, has the following meanings: a) the leaves of the tea-plant(参喿叶); b) a drink made by infusing these leaves in hot water (啉福水); c) the plant from which tea is obtained (茶树); d) a general name for infusions made in the same way as

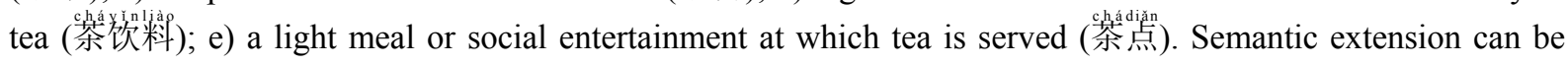
achieved by metaphorical calque. For example, Shanghai, the name of one of the chief seaports in China, acquired the meanings of: a) a long-legged, large breed of domestic fowls of Shanghai (浦槑然鸣): place for product metonymy; b) (U.S.) to drug or otherwise render insensible, and ship on board a vessel wanting hired

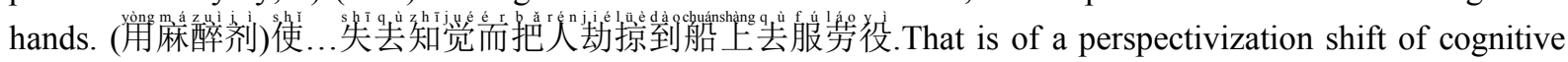
domain, and a mapping of static place into a dynamic one: a person drugged and submitted for labor service on board to Shanghai (destination for event). In a similar way, nankeen, originated from a city name Nankin(g), acquired the meaning of: a) a sturdy yellow or buff cotton cloth (采色色若: produced in Nanking); b) senses relating to this cloth (土棉希吊的); c) trousers made of nankeen (土土布裤); d) a blue and white porcelain of

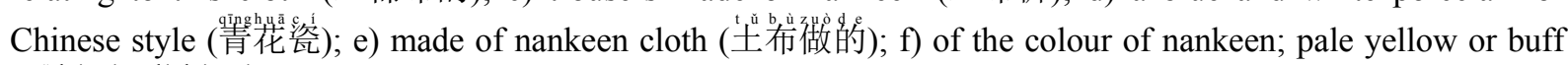

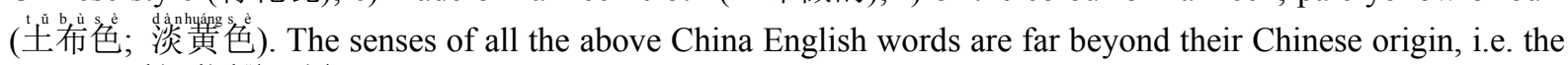

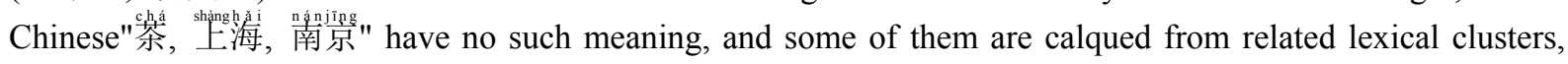
and some others from a particular association or metonymic extension.

\section{Conclusion}

Since British people came to China for trading in 1637, and English came in contact with Chinese, Chinese elements have become increasingly significant in English, and the latter has experienced considerable contact induced changes in various development stages of Chinese Englishes. Canton English and Pidgin English are commercial need-driven, they came into being, to a certain extent, as a language creation-a jargon characterized by both Chinese and English - in a very special period in China, and played an important part in China foreign trade, and have still contributed a great deal to today's China English. Chinese English, more or less affected by mother tongue transference and target language overgeneralization, is a norm-based, target-oriented transitional language; it is very China-specific. But some of Chinese English expressions, with increasing frequency of use, have been admitted into normative English, e.g., long time no see, no can do, to sit the month. As for Chinglish, it is a misused, nonsensical form of English, and must be rejected. China English is a norm-based new variety of world English with Chinese characteristics, and it is widely used in today's international communication. Although some China-specific expressions are hard for English natives to 
comprehend, with time and repeated occurrence in English media, English spelling people will soon get used to them. In fact, during the last three decades, China English has contributed tremendously to the international communication for globalization. Presently, 450 million Chinese people have learned or are learning English, which is a solid base for the global circulation of China English.

\section{References}

Bamgbose, A. (1998). Torn between the norms: Innovations in World Englishes. World Englishes, 17(1), 1-14. https://doi.org/10.1111/1467-971X.00078

Bolton, K. (2003). Chinese Englishes: A Sociolinguistic History. Cambridge: Cambridge University Press.

Bolton, K. (2012). Chinese Englishes: From Canton jargon to global English. Blackwell Publishers, Ltd.

Boretzky, N. (1991). Contact-induced sound change. Diachronica, 8, 1-16. https://doi.org/10.1075/dia.8.1.02bor

Cannon, G. (1988). Chinese borrowings in English. American Speech, 63, 3-33. https://doi.org/10.2307/455420

Cheng, C. (1992). Chinese varieties of English. In B. B. Kachru (Ed.), The Other Tongue: English Across Cultures (pp. 162-176). Urbana: University of Illinois Press.

Corder, S. P. (1981). Error Analysis and Interlanguage. Oxford: Oxford University Press.

Crystal, D. (1997). English as a Global Language. Cambridge: Cambridge University Press.

Cui, J. (2012). On the translation of Chinese current political new words. Theory and Practice in Language Studies, 2(5), 1075-1079. https://doi.org/10.4304/tpls.2.5.1075-1079

Danchev, B. (1988). Language contact and language change. Folia Linguistica, 22, 37-54. https://doi.org/10.1515/flin.1988.22.1-2.37

Davis, D. R. (2010). The inclusivity of World Englishes. World Englishes, 29(1), 21-26. https://doi.org/10.1111/j.1467-971X.2009.01622.x

Deterding, D., \& Sharbawi, S. (2013). Brunei English: A new variety in a multilingual society. Dordrecht: Springer. https://doi.org/10.1007/978-94-007-6347-0

Eaves, M. (2011). English, Chinglish or China English? Analysing Chinglish, Chinese English and China English. English Today, 27(4), 64-70. https://doi.org/10.1017/S0266078411000563

Ellis, R. (1987). Developing interlanguage through fluency. Focus on English, 3, 3.

Escure, G., \& Schwegler, A. (2004). Creoles, contact, and language change: linguistic and social implications. John Benjamins Publishing Co. https://doi.org/10.1075/cll.27

Gillard, P., \& Gadsby, A. (1998). Using a learner's corpus in compiling ELT dictionaries. In S. Granger (Ed.), Learner's English on Computer (pp. 159-171). London: Longman.

Haugen, E. (1950). The analysis of linguistic borrowing. Language, 26(2), 210-231. https://doi.org/10.2307/410058

He, D. (2015). University students' and teachers' perceptions of China English and World Englishes: Language attitudes and pedagogic implications. The Asian Journal of Applied Linguistics, 2(2), 65-76.

He, D., \& Zhang, Q. (2010). Native speaker norms and China English: From the perspective of learners and teachers in China. TESOL Quarterly, 44(4), 769-789. https://doi.org/10.5054/tq.2010.235995

Jette, G., \& Edwards, H. (2016). China English: Attitudes, legitimacy, and the native speaker construct: Is China English becoming accepted as a legitimate variety of English? English Today, 1, 1-8. https://doi.org/10.1017/S0266078416000171

Jia, G., \& Xiang, M. (1990). On China English. Foreign Languages and Foreign Languages' Teaching, 5, 5-7.

Jiang, X. (2001). China English in cross-cultural communication. The Journal of Si Chuan Foreign Languages' Institution, 6, 12-16.

Jiang, Y. (1995). Chinglish and China English. Journal of English Today, 11(1), 51-56. https://doi.org/10.1017/S0266078400008105

Jiang, Y. (2014). China English: Issues, Studies and Features. Asian Englishes, 5, 4-23. https://doi.org/10.1080/13488678.2002.10801095

Jiang, Y., \& Du, R. (2001). China English in the past 20 years. Foreign Language Teaching and Research, 1, $37-41$. 
Jiang, Y., \& Du, R. (2003). Issues on China English. Foreign Language Education, 24, $27-35$.

Jin, H. (2001). China English's pragmatic context and pragmatic function. Fu Jian Foreign Languages, 2, $12-$ 17.

Kachru, B. B. (1988). The sacred cows of English. English Today, 16, 3-13. https://doi.org/10.1017/S0266078400000973

Kachru, B. B. (1990). World Englishes and Applied Linguistics. World Englishes, 9(1), 3-30. https://doi.org/10.1111/j.1467-971X.1990.tb00683.x

Kachru, B. B. (Ed.). (1992). The other tongue: English across cultures. Urbana: University of Illinois Press.

Kachru, B. B. (1992a). Teaching World Englishes. In B. B. Kachru (Ed.), The Other Tongue (pp. 355-362). Urbana: University of Illinois Press.

Kachru, B. B. (1992b). World Englishes: Approaches, issues and resources. Language Teaching, 25, 1-14. https://doi.org/10.1017/S0261444800006583

Kerr, G. J. (2001). Getting it right—-from Chinglish to English. Shenzhen Daily, Feb. 5th.

Kirkpatrick, A. (2007). World Englishes: Implications for international communication and English language teaching. Cambridge: Cambridge University Press.

Kirkpatrick, A., \& Xu, Z. (2002). Chinese pragmatic norms and "China English". World Englishes, 21(2), 269279. https://doi.org/10.1111/1467-971X.00247

Kui, Z. (2011). On Chinese-English language contact through loanwords. English Language and Literature Studies, 1(2), 100-105. https://doi.org/10.5539/ells.v1n2p100

Li, W. (1993). China English and Chinglish. Foreign Language Teaching and Research, 4, 18-24.

Lipski, J. M. (1994). Latin American Spanish. New York: Longman.

Liu, J. (2008). China English and its linguistic features. The International Journal of Language Society and Culture, 25, 27-35.

Matsuda, A. (2003). Incorporating World Englishes in teaching English as an international language. TESOL Quarterly, 37(4), 719-729. https://doi.org/10.2307/3588220

Matsuda, A., \& Friedrich, P. (2011). English as an international language: A curriculum blueprint. World Englishes, 30(3), 332-344. https://doi.org/10.1111/j.1467-971X.2011.01717.x

Meeuwis, M. (1991). A pragmatic perspective on contact-induced language change. Pragmatics, 1, 481-516. https://doi.org/10.1075/prag.1.4.04mee

Moravcsik, E. (1978). Universals of language contact. In J. Greenberg (Ed.), Universals of human language (pp. 94-122). Redwood: Stanford University Press.

Morrison, J. R. (1823). A Dictionary of the Chinese Language, in Three Parts: English and Chinese. MACAO: Printed at the Honorable the East India Company's Press by P. P. Thoms.

Muysken, P. (2013). Language contact outcomes as the result of bilingual optimization strategies. Bilingualism: Language and Cognition, 16, 709-730. https://doi.org/10.1017/S1366728912000727

Poon, F. K. C. (2006). Hong Kong English, China English and World English. English Today, 22(6), 23-28. https://doi.org/10.1017/S0266078406002045

Selinker, L. (1972). Interlanguage. International Review of Applied Linguistics, 10(3), 209-231. https://doi.org/10.1515/iral.1972.10.1-4.209

Shi, X. (2014). Chinese-characterized terms translation on the functional equivalence theory. Journal of Language Teaching and Research, 5(5), 1116-1120. https://doi.org/10.4304/j1tr.5.5.1116-1120

Shu, D. (1996). Modern Foreign Language Teaching. Shanghai: Shanghai Foreign Language Education Press.

Silva-Corvalán, C. (1994). Language Contact and Change. Clarendon Press.

Singh, R. (1995). Discussion note on "New/Non-native" Englishes: A Quartet. Journal of Pragmatics, 24, $383-$ 385. https://doi.org/10.1016/0378-2166(94)00046-H

Smith, L. E. (1983). English as an International Language. Readings in English as an International Language. Oxford: Pergamon Press. 
Thomason, S. G. (2001). Language Contact. Washington: Georgetown UP. https://doi.org/10.1016/B0-08-043076-7/03032-1

Todd, L., \& Hancock, L. (1986). International English Usage. New York: New York University Press.

Treffers-Daller, J. (1999). Borrowing and shift-induced interference: Contrasting patterns in French-Germanic contact in Brussels and Strasbourg. Bilingualism: Language and Cognition, 2, 1-22. https://doi.org/10.1017/S1366728999000115

Trigault, N. (1626). Xiru Ermu Zi (Aid to the Eyes and Ears of Western Literati). Language Reform Publishing House.

Wang, R. (1991). China English is an objective reality. Journal of PLA University of Foreign Languages, 1, 1$8+56$.

Weinreich, U. (1953/1979). Language in Contact: Findings and Problems. The Hagues, Paris, New York: Mouton publishers.

Williams, S. W. (1836). Chinese Repository, 4(9).

Williams, S. W. (1856). Ying Wá Fan Wan Tsüt Lú: A tonic dictionary of the Chinese language in the Canton dialect. Canton, The Chinese Repository, 792.

Williams, S. W. (1874). A syllabic dictionary of the Chinese language. Shanghai American Presbyterian Mission Press.

Winford, D. (2003). Introduction to contact linguistics. Oxford: Blackwell Publishing.

Winford, D. (2005). Contact-induced changes: Classification and processes. Diachronica, 22, 373-427. https://doi.org/10.1075/dia.22.2.05win

Winford, D. (2009). On the unity of contact phenomena: The case of borrowing. In K. De Bot, L. Isurin \& D. Winford (Eds.), Multidisciplinary perspectives on code-switching (pp. 279-305). Amsterdam: John Benjamins. https://doi.org/10.1075/sibil.41.15win

Wu, W. (1998). On the translation of Chinese slogans. Chinese Translators Journal, 1, 35-38.

Wu, Y. (2001). Pidgin English and Sino-Western intercourse before the Mid-19th Century. Modern Chinese History Studies, 3, 172-202.

Xie Z. (1995). China English: The variety in verbal cross-cultural communication. Foreign Languages of the Modern Times, 1, 8-10.

Zhang, A. (1997). China English and Chinese English. English Today, 13(4), 39-41. https://doi.org/10.1017/S0266078400010002

Zhang, X., \& Shi, Y. (2008). English translation of culture-specific lexicon commonly seen in Huangdi Neijing. Chinese Journal of Integrated traditional and Western Medicine, 28(10), 941-944.

Zhou, Y. (2012). A tentative study on lexical characteristics of China English. International Conference on Arts, Economics and Literature (ICAEL 2012), December 14-15, 2012, Singapore.

Zhou, Z. (2005). A decipher on manuscript of Canton English kept in British Library. Jinan Shixue (Jinan Historiography), 4, 333-353.

Zhou, Z. (2013). The Creation of Chinese Pidgin English. Fudan Journal (Social Sciences), 5, 1-18.

\section{Notes}

Note 1. All lexical examples in this paper are extracted or cited from these four linguistic sources unless annotated otherwise.

Note 2. All these are quoted from actual public signs. For example, the last two are respectively from a Chengdu Shuangliu International Airport shuttle bus and a super-market.

Note 3. All the examples are quoted from the Chinese Learner English Corpus (CLEC). ST5 refers to first- and second-year university students majoring in English, ST6 to third and fourth year; ST3 and ST4 refer to students at the College English level 4 and 6 respectively; ST2 to a secondary school student.

Note 4. This conclusion is exclusively based on the sub-corpora of International Corpus of Learner English, i.e. English learner's corpus with different mother tongue backgrounds: German, Italian, and Swedish. The statistics 
show that only two errors of this kind are found: most great and according to my opinion.

Note 5. These collocation instances are extracted from the CLEC, and the corrections are given in brackets by the authors.

Note 6. http://atilf.atilf.fr/

Note 7. This is an early use in representations of North American Indian speech. [Apparently $<$ Chinese Pidgin English, after Chinese hăojiǔ bú jiàn (< hăojĭu long (time), lit. 'good long (time)' + bù not, no + jiàn to see, meet) and (with a different word for 'not') hăojĭu méi jiàn. -- OED

\section{Copyrights}

Copyright for this article is retained by the author, with first publication rights granted to the journal.

This is an open-access article distributed under the terms and conditions of the Creative Commons Attribution license (http://creativecommons.org/licenses/by/4.0/). 